\title{
Re-imagining the Writing \\ Workshop: The Creation of \\ Multilingual, Collaborative Poetry
}

\section{Kobus Moolman}

The poem starts with desire

There is no idea, words or rhythm

Only a vague nameless desire

Then you climb dark stairs

As if they are not there, or yet to appear

You climb fearing that you might trip and break your heel

But when you place your foot in the last step

Light emanates

As if a shut door was suddenly flung to the sun

You see the stairs you climbed

The stairs you built

Then you come down happy

To count the steps you made and climbed.

- Zakaria Mohammed, extract from "Eight Poems"

W That is a creative writing workshop? Why run a writing workshop for a group of young students who have had no prior experience in writing and who therefore have little idea of what creative writing actually is? What can realistically be achieved in or expected from a once-off four-hour writing workshop? And how do writing and multilingualism and the ethics of de-coloniality intersect in the context of a twenty-first century South African university?
In 2018 I was asked to conduct a multilingual writing workshop for a combined group of Linguistics Honours students from the University of the Western Cape (UWC) and Stellenbosch University (SU). The Centre for Multilingualism and Diversities Research (CMDR) and the Departments of Linguistics at SU and UWC had devised a new postgraduate module on multilingualism, entitled 'Re-imagining Multilingualisms'. The purpose of the module was to explore issues of 
multilingualism and transformation in higher education pedagogy and practice. A range of theoretical and creative seminars (including visual arts and writing) were structured into the course in order to 'explore alternative understandings of multilingualism by developing ways of re-imagining language that tap into the embodied and historically lived linguistic experiences of students [my emphasis]' (2018 Course description).

The emphasis here upon an embodied learning experience as an alternative to the old hierarchical model in which the learners bring almost nothing of themselves to learning and are rather to be filled like the proverbial empty vessels, excited and attracted me as a writing teacher. Creative writing is foremost a way of thinking, in and through literary expression. It foregrounds learning not so much as about, as through and by means of. And the through of this practice is both an affirmation of process over endgoal, and an avowal of each student's linguistic, cultural and personal story: an affirmation in short of their own voice and their right to voice. My challenge as a writing teacher then was how to devise a workshop (which would only take more or less four hours) that best enabled different voices to emerge confidently in a diversity of languages - without one (inevitably English) dominating and that thereby allowed students to engage with each other's different, but overlapping, perspectives.

It is important to stress that multilingualism is not just a transformatory pedagogic principle that returns students to that which they know rather than that which they do not, but it is also an affirmatory and liberatory writing practice. Stacy Hardy, editor of the Pan-African journal, Chimurenga, writes: 'By allowing other languages' influences into any language, we allow other rhythms, syntax, vocabularies, cultural contexts and movements to disturb and affect that language, to alter it. This is the politics of space and body, sound, reaction to sound, to the way a word looks on the page and how it feels in the body' (2015: 27).

A brainstorming session with Zannie Bock from the UWC Linguistics department gave rise to the idea of small groups of students producing collaborative multilingual poems in the workshop, rather than individually composed pieces. The intention was to move participants from the insecurity and self-judgment of individual composition to the self-confidence and solidarity of a collaborative improvisatory ideal.

The aim would be to explore multilingualism in practice and to engage in negotiation and accommodation through an inclusive compositional process. This would be achieved through a collaborative process that engaged students in cooperative strategies and a form of verbal engineering, whereby they would learn to make decisions as a group regarding literary elements such as pattern, repetition, character and symbolism - bearing in mind all the time, of course, that the actual aim of the workshop was not the teaching and learning of these elements, but their indirect and perhaps even unconscious employment in a larger project of inclusivity and diversity.

There is an intriguing parallel between the methods of collaborative writing used here and those of workshop theatre, particularly as practised in South Africa. The Cape Town theatre director and academic, Mark Fleishman, argues that workshop theatre is a form based on the principles of democracy: 'Workshopping is a democratic, playful and responsive form wherein the director facilitates and shapes a piece 
from work generated by the company. Its aims are not solely the creation of a polished product for the stage; the process also instils a sense of pride and dignity, self-confidence and solidarity in its participants' (1990: 111).

In such a practice, the principle facilitator (myself in this case) is not situated outside the learning experience in a position of authority and omniscience. If the facilitator were to do so then immediately the participants would begin to doubt the validity of their own personal experiences (right or wrong / unacceptable or unacceptable), and they would lose confidence and silence themselves, and the collaborative ideal would break down. Instead the facilitator walks the journey alongside the participants, not having any privileged knowledge as to where they are going or how they will get there. Doubtless, this practice of what I would call 'willing ignorance' can be challenging for some teachers, but it foregrounds learning as a shared experience of discovery, of something coming into revelation, and in so doing it invigorates new methodologies of teaching and learning that coincide with the transformatory project at South African institutions of higher education. Furthermore, it draws attention to something at the heart of all creative processes: that we do not necessarily need to think before we write or paint, that writing and painting are ways of thinking in and of themselves. As E. M. Forster wrote: 'How do I know what I think before I see what I say?' (Moore 2012: 103).

But the workshop method also highlights the fact that processes of creativity require more than the application of concentrated effort or so-called talent; they require relaxation, space and the right amount of pressure provided by a prompt and a timeframe.
This brings me then to the actual writing practices that were employed in the workshop and how I implemented these on a practical basis. Here I must make mention of two Masters students, Lisa Julie and Nondwe Mpuma, who assisted me on the day. Lisa and Nondwe are senior Creative Writing students whose distinctive lyrical poetry has been published locally and abroad.

In the workshop my co-facilitators and I sought to explore a range of diverse ways of drawing upon and drawing out the affective stories of each of the participants, based around a central theme: the idea of Home. The workshop was divided into two sections - divided by a convenient (and, as per UWC practice, very delicious) lunch. The first part of the day was given over to individual work, and began by exploring a range of sequentially organised ideas, including memory, observation and imagination. These were all brainstormed and composed spontaneously using the technique of free writing. After lunch the participants were divided into three groups and the different ideas - conceptual and concrete - were drawn together in a collaborative and improvisatory manner in a single multi-authored and multilingual poem.

Free writing exercises are a staple feature of many writing workshops, and are easily adapted to large and small groups and to a range of writing abilities. In his article, 'Whose Voice is it Anyway? Implications of Free Writing' Anton Krueger (2015: 103) from the Department of Drama at Rhodes University, explores the beneficial characteristics of this methodology:

Giving students a theme, a quote, an object or a picture to spur on their creativity can be less daunting than demanding that they come up with something from nothing. The 
imagination is given a springboard into the unknown, and having permission to play, experiment (and fail) can help students evade blockages which come from trying too hard. One needs to find a way of coaxing a text into being, and remain wary of bludgeoning a seed of inspiration into submission with attempts at overt control. Every game requires limits, and the structure of a free writing workshop involves setting a limit in terms of time, or length. Students write without pausing and then typically read back to the group what they've just written. . . . The exercise is not necessarily about writing quickly, but about writing without pausing. One wants to create a flow, and it's difficult to find a rhythm if one keeps stopping and starting. In doing so, one also hopes to momentarily override one's overly critical faculties.

The emphasis that Krueger places here on freedom from fear of judgment (not being good enough, not knowing how to write 'properly') is critical and relates directly back to the transformatory project of a decolonial pedagogy, since, as Krueger continues, if free writing exercises take place in a supportive environment which encourages play and improvisation, they can build confidence in the act of writing' (2015: 104). The uniqueness of such a supportive improvisatory space is that it encourages participants to 'both relax and take risks', according to Michael Rabiger (2005: 22), and so promotes flexibility and adaptability in thinking and in writing.

The prompts that I used in the free writing exercises were not arbitrary. They related to the overall theme of 'Home' and were devised in order to focus participants on developing their skills of observation and memory. The prompts were also always linked to various readings that I had selected and prepared for the workshops. These readings were taken from various contemporary South African poets. In the main, the poets were young and black, although not exclusively. They included Mangaliso Buzani, Sindiswa Busuku-Mathese, Ayanda Billie, Koleka Putuma and Kelwyn Sole. As well as material by some of our postgraduate creative writing students: Lisa Julie, Nondwe Mpuma, Kerry Hammerton and Musa Khanyile. I also featured the long prose poem, "Conversations about Home" by the British-Somali poet Warsan Shire. All of the material used a clear and direct register and focussed the reader's attention on the quotidian, especially the everyday of township life, what Njabulo Ndebele would refer to as the 'ordinary' rather than the 'spectacular'. In this way participants in the workshop were brought gradually out of a space of comparison and evaluation (judging their lives in relation to others in the class) and into a place of quiet affirmation and dignity. This related, of course, back to the creation of the type of 'supportive environment' that was vital for free improvisatory writing and to a new form of learning that validated each person's experiences and eschewed judgment.

When it came to the creation of the multilingual and multi-authored poem, Nondwe, Lisa and I each took responsibility for one of the three groups as guide and informal mentor; essentially someone who asked questions in order to 'spur creativity' rather than provided answers. We discovered that there were students with a range of linguistic backgrounds; these included not just obviously English and Afrikaans, isiXhosa and isiZulu, but also Brazilian 
Portuguese and a smattering of German - although the latter did not appear in any of the final poems.

I made use of simple brainstorming techniques to build up a long list of personal responses to Home, and the differences between Home and House; how House could home a Home, but Home was not necessarily a House. What did it mean to be at Home? What were the participants' personal memories of Home? How were these memories carried along and evoked by the five senses: the smell of Home, the sound of Home? etc. And, interestingly, what was the relationship between being at home and being in this new transformatory type of workshop space? As a group, this list was then gradually whittled down to remove unnecessary repetition and unrelated facts, and to highlight the crucial parts. And together we then worked out an order for the different responses so that there was an entry point for the whole piece, some kind of narrative or movement, and then a general closing off.

Importantly, participants were encouraged to respond in their own home languages. And the safe and trusting space of the workshop that was established in the morning's free writing exercises, allowed them to both speak in their own tongues and to proffer responses that were nostalgic and even vulnerable.

My two co-facilitators selected specific spaces in the Home (the kitchen, for example), and then gathered a range of sensory responses related to that particular space. Their individual articles in this journal provide more detail on their working methods and their objectives. The three final pieces are also reproduced in this journal.
The workshop then ended with readings or performances of the three collaborative poems, with different students reciting certain sections of the final product, depending on home language. There was much laughter, clicking of fingers and otherwise general appreciation of participants' courage in sharing, and a mutual recognition of the memories and feelings that connected rather than divided them.

In this way the workshop successfully drew students from a range of disparate backgrounds together, in a single non-judgmental space, where they could respond to prompts in their own language, and so come to a freeing place of understanding the world through each other's senses. And this surely was an embodied and lived experience of what transformation in higher education pedagogy could be.

\section{REFERENCES:}

Fleishman, M. 1990. 'Workshop Theatre as Oppositional Form.' South African Theatre Journal, 4(1): 88-118.

Hardy, S. 2017. "The Body or the Academy or the Creative Teacher." The Fertile Ground of Misfortune: Teaching Practices in Creative Writing. eds Hardy, S and Berold, R. Institute for the Study of English in Africa: Grahamstown.

Krueger, A. 2015. "Whose Voice is it Anyway? Implications of Free Writing." Current Writing: Text and Reception in Southern Africa, 27(2): 103-110.

Mohammed, Z. 2014. Kushtuban. Trans. Sinan Antoon. Amman/Ramallah: Dar al-Nashir Press.

Moore, D. 2012. Mindful Writing: The Four Noble Truths of the Writing Life. Boston: Wisdom Publications.

Rabiger, M. 2005. Developing Story Ideas. Massachusetts: Focal Press. 


\section{Collaborative Multilingual Poem \# 1}

\section{Tuiskoms}

"Hallo Jennatjie,

Molo nana,

Welcome home Jaybird"

When I come home I see my grandmother's back

She is planting seeds in the garden:

Imbuya noBhatata.

I can smell the sticky sweet sugarcane across the canal.

Her dogs run out to meet me, barking their greeting

As if to say

"ubuyil' uthunjana ka ma”.

She turns around and straightens up slowly

“ag jirrie, ko' help vi' mamma”

Her body has aged

But her smile remains the same

I hope not much has changed.

Amy Palmer, Steph Aitchison, A. Braaf, Veronique Williams, Ndimphiwe Bontiya, Sima Mashazi, Sinovuyo Nikani, Nicole Jansen, Gené Van Wyk, Mishka Bal,

Kobus Moolman.

Molo nana - hi nana (nana is a common vocative among several South African languages)

Imbuya nobhatata - wild spinach and sweet potato (isiXhosa)

ubuyil' uthunjana ka ma-Mommy's last born/baby/youngest has come back (isiXhosa)

ag jirrie, ko' help vi' mamma - Agh come help mamma (Kaaps) 


\section{Collaborative Multilingual Poem \#2}

\section{Home}

The smell of Rooibos tea, dust, damp with sunlight liquid, my ma se groente bredie.

Home smells like something musty, my mother's biscuit scent, like artificial dust from burning rubber on tar. Home smells like Dahl and Roti, burning oats with the stuffiness of morning. . . coffee.

sweet and spicy, earthy apples.

Home tastes like an escape, chicken.

My home tastes like patriarchy, umngqusho, and opens.

Home tastes like chokers en survivors.

lived in, my mother's vision of a hotel room.

Home looks like open doors and windows.

Home is agter trallies.

Home is wide-open spaces.

Home is peeling paint and posh neighbours.

Ghostly memories.

dogs barking, laughter, DSTV premium package.

Home sounds like my mom yelling, "My kinders is by die huis!"

"Tshepiso! Hamba! Hlamba izitya!"

Home:

something recognisable yet unknown.

"Namaste"

Shannon Cogill, Peter Msaka, Charné Pretorius, Jayde Mcloughlin, Melanie Snell, Tshepiso Titipana, Engela de Villiers, Minali Parshotam, Jason Richardson, Nondwe Mpuma.

my ma se groente bredie - my mother's vegetable stew (Afrikaans)

umngqusho - an isiXhosa name for a samp and beans dish

chokers en survivors - a Kaaps term for a peanut butter and jam sandwich

agter trallies - behind bars (Afrikaans)

My kinders is by die huis - My kids are at home (Afrikaans)

Tshepiso! Hamba! Hlamba izitya - Tshepiso! Go! Wash the dishes! (isiXhosa)

Namaste - I bow to the divine in you (Sanskrit) 


\section{Writing and Editing "Home": A Reflection}

\section{Nondwe Mpuma}

7 his piece presents my reflections on facilitating the writing of the collaborative, multilingual poem, "Home". The workshop began with a series of free writes where Professor Kobus Moolman provided prompts that were in one way or another linked to the concept of home. In the workshop, there was a discussion about how poetry involves all the five senses and how every person in the room had to try and connect to 'the language that one dreams in'. This idea took hold in the conceptualisation of our collaborative poem titled "Home." I decided to lead the group in the direction of using the senses as an anchor around which we could draw a picture of home with words. The intent was that the poem would invoke a sense of home through touch, taste, smell, look and sound. The students had the opportunity to play with all the ideas that they had about home, and they were also able to play with words, language and meaning with very few constraints. As a group we read aloud our free writes guided by the senses and went through an editing process that focused on how the poem sounded.

In the process of writing this reflection, I pondered over a number of questions such as: how do we determine that a piece of poetry is multilingual when there is a dominance of one language over other languages? How do we understand multilingualism beyond the usage of many languages in the creation of poetry? Finally, how do we guide the compilation of such a poem and its editing process when there are so many lapses in our understanding of the languages that we are not proficient in? I attempt to pose possible answers to these questions through reflecting on the writing, compilation and editing of "Home." In a letter, 20 ${ }^{\text {th }}$ century American poet William Carlos Williams (he is closely associated with the literary movements of modernism and imagism), wrote to Marianne Moore: 
I want to call my book:

A Book of Poems:

AL QUE QUIERE!

- which means: 'To him who wants it' - but I like the Spanish just as I like a Chinese image cut out of stone: it is decorative and has a certain integral charm. But such a title is not democratic - does not truly represent the contents of the book, so I have added:

A Book of Poems:

AL QUE QUIERE!

or

\section{THE PLEASURES OF DEMOCRACY}

Now I like this conglomerate title! It is nearly a perfect image of my own grinning mug (seen from the inside), but my publisher objects - and I shake and wobble (Williams 2017: i).

This is the manner in which I would like to think of all three collaborative poems, as conglomerations of voice, space and place leading from the notion of home. In the group that I was facilitating, I impressed on them the importance of being specific in how we described home in order for us to create clear scenes. "Home" is written predominantly in English while it also features Afrikaans, Sanskrit, Kaaps and IsiXhosa. We decided on a simple title, "Home," because it reflected the sentiments of the body of the poem. The majority of the poem works by association, where 'Rooibos tea', and 'groente bredie,' are not only Afrikaans but they also invoke the locality of the Cape, on the other hand 'Dahl' and 'Roti' are words that originate from the Indian subcontinent and in this context invoke the presence of Indian cultures; similarly with 'umngqusho' (a distinctly South African dish of samp and beans) and 'chokers en survivors' (a peanut butter and jam sandwich) indicating a presence of Kaaps in the poem. It is in these associations that the poem is multilingual.

In retrospect, I think that our poem works with association because of how we use English integrated with other languages when we speak socially with people who are multilingual. I impressed upon the group the importance of how our poem would sound. In poetic terms, the importance of rhythm influenced how we compiled the poem together. As we decided to structure the poem along the senses, we had to read the poem aloud every time we put lines together and subsequently rearranged them. The conversation that we had as we were compiling the poem was mainly around how we would merge very concise imagery with more figurative elements. We also had a long conversation on what we could take away from the poem so that the rhythm was either made more consistent or was not lost. As a result, the 
poem does not have a specific author. I cannot remember who came up with which line and I guess putting any emphasis on the individual ownership of the poem would undermine the collaborative process in any case.

We then come to the problem of transcribing: we had one scribe whose primary role was to record the poem throughout the process. I relate this process to playing broken telephone as there were words that were either missed, misspelt or misheard and as the editors of the journal and workshop assistants, Lisa and I have been tasked with resolving these issues as a matter of clarity rather than an act of taking liberties with the collaborative work. Two examples of this are that, the line, 'chokers en survivors', was originally transcribed as "chokers and survivors', 'groente' was incorrectly spelt as 'gronte' and 'umngqusho' was misspelt as 'umgqusho'. The line, 'Tshepiso! Hamba! Hlamba izitya! was initially transcribed as, 'Tsepiso hambla hlamba izitya', but edited for the sake of clarity. The punctuation here indicates tone and the pauses that are necessary for meaning making in this line of the poem. These examples indicate the delicacy, and caution that I have had to exercise in the editing process post the writing of "Home." I had to ask for assistance from Lisa to help me correct any Afrikaans spelling mistakes.

Writing about home forced us to face whatever thoughts and feelings we had about the space and place. We had to confront those in a very pointed manner and as we reached the fourth stanza, I asked 'what does home feel like?' I had my own answers to that question but they were lengthy and complicated and the answers to the question were like mine, long and complicated. Someone in our group had written about staying on campus and not being at home and how home had become 'something recognisable yet unknown'. This, when combined with the final line, "Namaste", meaning 'I bow to the divine in you', seemed and still reads like the perfect wording to hold together the complexity that surrounds the idea of home.

Dialogue had to take place for "Home" to emerge. The dialogue, writing and construction took place in the space of an hour. It is remarkable that much can be said of this process as this time is limited compared to how long it takes me to write and edit my own work. The poem offers a multivocal painting of home and I find that my reflection does not do this work much justice. I return to William Carlos Williams where I see "Home" as being a nearly perfect image of the voices of its many authors.

\section{REFERENGES:}

Williams, William Carlos. 2017 (1917). A Book of Poems: Al Que Quiere! Edited by Jonathan Cohen. New York: New Directions. 


\section{Collaborative Multilingual Poem \#3}

\section{Quebre O Forno}

Rice is boiling, steaming windows, borbulhando

prut.

Each time I enter the kitchen I ask myself: Why a TV?

Why a pile of dishes?

Why a spoon in the microwave?

Each time I enter the kitchen

I hear: What's for supper?

Who opened another milk?

Ek bly in 'n huis in La-la dorp

Is die huis mense hier?

Ndayiqonda ndihlala kumzi owawuhlala umama iimbiza zatsha!

Lisa Julie, Asithandile Nozemi, Caitlin O'Donovan, Lulu Duke, Taryn Dick, Marcelyn Oostendorp, Anna Isabel Freire, Fernanda Alencar Pereira, Keshia R. Jansen, Lauren Abrahams.

Quebre o Forno - Brazilian Portuguese for 'break the oven'

Borbulhando - word meaning simmering/bubbling (Portuguese)

prut - simmering (Afrikaans)

Ek bly in 'n huis in La-la dorp/ Is die huis mense hier? - I live in a house in La-la land or town/ are the homeowners present? (Afrikaans)

Ndayiqonda ndihlala kumzi owawuhlala umama iimbiza zatsha - I understood that I live in the house that my mother lived in and the pots burned (isiXhosa) 


\section{On writing and editing a multilingual poem: "Quebre o Forno"}

\section{Lisa Julie}

"Quebre o Forno" is one of the multilingual, collaborative poems to emerge from the creative writing workshop. It incorporates a total of five languages: isiXhosa, Afrikaans, English, isiZulu, and Portuguese. I began the writing process with a conversation about the given topic which was centred on the concept of 'home'. We were encouraged to write about the more far-reaching connotations of Home as opposed to just the physical space, in other words, we explored ideas such as memory and longing. I anticipated a sense of nervousness from the students about writing their own poetry especially in relation to the given topic. I am also aware that many people view poetry as a somewhat intimate and personal literary genre, not easily shared. My intention was not to correct any misconceptions regarding poetry or about writing poetry. However, I wanted to show that writing poetry is a craft which requires skill, experience and a willingness to play.

\section{ON WRITING A MULTILINGUAL POEM}

I suggested that we try and write a poem using 'concrete imagery'; that we try and create a poem comprised of vivid descriptions. I wanted the strength (or the poignancy) of our poem to stem from our descriptions. We then decided that we would write a poem that explores actuality opposed to abstract ideas. During our discussion or what one might call the 'pre-writing' stage, we spoke about

Zannie Bock <zannie.bock@gmail.com>

Mon, Nov 5, 2018, 8:41 PM

to Nondwe, Lisa

Dear Nondwe and Lisa

I would like, if possible, to understand the meanings of some of the words in the attached poem - from the workshop you did with our students.

Lisa, how would you translate 'boerbulhandsprut'? And do you remember what meaning it had for the group?

And why 'Laladorp' > is that like 'sleepy town'? 
all of the idiosyncratic particularities of our own homes. We spoke about chipped walls, overgrown hedges, specific smells and sounds. Writing about home is by nature, quite sensitive. However, I continued to encourage the students to fictionalise certain aspects in their descriptions; to fictionalise the chipped walls and the overgrown hedges. In fact, I quite distinctly remember quoting Emily Dickinson's - 'Tell all the truth but tell it slant'.

The conversations seemed to have gone on for quite a long time. However, I do remember us spending the bulk of our pre-writing time in the kitchen. I should probably say that our group was comprised entirely of women and the conversations seemed to flow quite freely; we seemed to share similar grievances and similar frustrations. We spoke about the unusual habits of our individual significant others. We spoke about overflowing sinks and the one question many of us dread -What's for supper?

It then occurred to us that it would be quite interesting and almost organic to place the beginning of the poem in the kitchen, which led to the title. "Quebre o Forno" translates to 'Break the Oven' and is Brazilian Portuguese. I was rather fortunate to have a group of diverse women from all sorts of interesting places. One of the poem's contributors told us about an old feminist tradition in certain parts of Brazil where women literally smashed their ovens into smithereens in a kind of protest against gender roles. We thought it would be interesting to use this as the title as it seemed to coincide with the conversations we were having. At the same time, we wanted to create a sense of tension within the space. This is essentially what the opening lines allude to - 'Rice is boiling, steaming windows, borbulhando, prut' (1-2). This is also the first instance in which we explored multilingualism.

My understanding of a multilingual poem is that it uses two or more languages. Multilingual poems usually feature one main language (that makes up the most of the poem) but is broken up by phrases or words in other languages. This is essentially what we aimed to do. If one were to do a translation of the first few lines, it is evident that we said the same thing (or made the same statement) in three languages. The word borbulhando is Portuguese for simmering as is the word prut in Afrikaans. It may seem redundant, but I believe that the essence of a multilingual poem is that each of the languages serves an aesthetic or a semantic purpose which is

Nondwe, can you help with the Xhosa sentence at the end of the poem?

If you could get back to me by Tuesday evening, I would be most grateful as I wanted to talk about the module at a conference where I am in Brazil, and I wanted to show this poem as it has some Brazilian Portuguese in!

Thank you so much,

Nondwe Mpuma <nmpuma@gmail.com>

Nov 6, 2018, 10:11 AM

Dear Zannie, 
what we achieved in this instance. The idea behind the repetition also speaks to the idea of wanting to record all of the voices present, and one assumes that a multilingual poem represents multitudinous voices. Additionally, (and perhaps incidentally) the words also seemed to generate a particular rhythm and tone for the rest of the poem. I suppose this has something to do with the assonance in borbulhando, followed by the deliberateness in the Afrikaans word prut. This is one example of the many potentialities of a multilingual poem. The idea that we were able to shift between languages allowed us to create a specific sound and rhythm, and also gave the poem a distinctive character. We followed this pattern throughout the writing of the poem, looking for instances in which we could add to the aesthetics as well as the rhythm.

I would like to draw some attention to the final stanza. The final stanza represents a significant shift in the underlying themes of the poem. The line 'Ek bly in 'n huis in La-la dorp' is an expression in colloquial language which alludes to ideas of 'societal exclusion' or 'not belonging'. A literal translation would read 'I live in a house in La-la town' but a more 'accepted' translation would read -'I live in a house in La-la land'. However, it is the succeeding line that truly captures the thematic shift. The line, 'Is die huis mense hier?' in this context, is a question directed at an individual of colour living in a previously white suburb. A literal translation of the line reads -'Are the homeowners present?' The line therefore refers to a very complex history surrounding domestic workers in South Africa. It paints a vivid image of an individual of colour opening a door and being asked 'Are the [white] homeowners present?' the assumption being they could not be the homeowner as they are not white. It also paints a picture of the continuation of race and class structures in a postApartheid setting. The line therefore represents a shift from the kitchen to a larger social setting. It also suggests a thematic change from the common frustrations of women or homemakers to ideas concerned with identity.

Although we tried to steer away from personal narratives, it is quite difficult to do so in some instances. Writing about home is undoubtedly a personal endeavour. It is a concept or topic that conjures up personal memories. Although I encouraged the students to 'fictionalise' in as many instances as they could, depersonalising the writing would surely have restrained their creativity.

This is the translation of the Xhosa sentence:

'I understood it when I stayed at the house that my mother lived in, the pots burned.'

Best regards,

Nondwe

Lisa Julie <lilyjulie68@gmail.com>

Nov 6, 2018, 4:08 PM

to me 
Writing about home is a universal concept which makes it a dynamic experience. A multilingual poem has the potential to explore this dynamism to an even further extent because it incorporates multitudinous voices.

\section{EDITING A MULTILINGUAL POEM}

Apart from making the poem as 'readable' as possible, the main challenge in editing "Quebre o Forno" had to do with maintaining the authenticity of the voices. I have only just begun to understand why the writing of the poem was far less delicate than the editing of the poem. I would like to draw on two points regarding the editing of this poem. Throughout the editing process, two questions or two problems seemed to resurface:

1. How do I correct a language that I do not speak and to what extent is correction required?

2. And how do I protect the authenticity of the individual and the collective voices?

Editing creative work has a lot to do with readership and accessibility. As a writer and scholar of literature, I am able to recognise awkward language and grammatical mistakes quite easily. However, I struggled to apply the same lens that I would for my own creative work in the editing of "Quebre o Forno". In all my attempts to answer the questions that seemed to resurface, I have come to the conclusion that a multilingual poem requires its own lens. This argument is based on the fact that the multilingual poem (in this instance) was a collaborative effort and the editing of this piece therefore required a similar kind of collective effort.

Throughout the workshop I continued to think about the rich history of collaborative poetry, the 'virtuoso circles', the Renga, the Renku as well as the Griot poetry of West Africa. As I attempted to edit "Quebre o Forno" I tried to imagine the processes they would have undergone without the conveniences of email and other present day communicative mediums. My argument is that "Quebre o Forno" was completely reliant on "virtual correspondence'. It required a collective re-engagement. The editing of "Quebre o Forno" required more than my own red pen, it required several red pens through various mediums. In relation to the second question that I posed regarding voice, I will begin with the title. The

\section{Dear Zannie,}

I'm afraid it's been misspelled. It's meant to be "borbulhando" which is the Portuguese (Brazilian) for simmering/boiling. "prut" is die Afrikaans.

The bit about "ek bly in $\mathrm{n}$ Lala dorp" refers to feeling out of place.

The poem is essentially about questioning conventions and feeling out of place. The speaker feels like she's the pot of rice, simmering on the stove.

I will message Nondwe to confirm the Xhosa.

One more thing, the line "is die huis mense hier" is a question that the speaker is often asked. 
title is really where the first problem emerged. In one electronic version of the poem, there was a misspelling - it read "Quebre o Form". This mistranslation interestingly translates to "Break the Form" and does not necessarily take away from the feminist ideals we set out to represent. However, it erased the historical commentary that we intended to make: the backstory which is directly linked to the word forno. This is something that I was not willing to compromise. This also highlighted the sensitivity to language that I needed to maintain throughout the editing of the poem. This misspelling was brought to my attention by the Portuguese speaking contributor Fernanda Alencar Pereira. The first transcription is re-copied here:

\section{Quebre o form}

Rice is boiling steaming windows borbulhandoprut

Each time I enter the kitchen I ask myself - why a TV?

Why a pile of dishes?

Why a spoon in the Microwave?

Each time I enter the kitchen

I hear - what's for supper?

Who opened another milk?

Who left the milk out?

Ek by in n' huis in Lala dorp

Is die huis mense hier?

Ndayiqonda ndihlala Kumzi Owawuhlala umama Imbiza zatsha!!!

She is not white and therefore it is assumed that she does not live in the house in "Lala dorp"

Lisa Julie <lilyjulie68@gmail.com>

Tue, Nov 6, 2018, 5:09 PM

to me

Dear Zannie,

This is what the Xhosa translates as (very loosely):

I realised I live in a home where my mother lived, where pots have been before.

(C) Julie and CMDR. 2019 
In the same version of the poem, the words borbulhando and prut are not separated. This is perhaps another case of misspelling. However, had this not been corrected, the poem would not have generated the same intended rhythm. I should include that the first electronic version of the poem was transcribed from a handwritten document (see Plate 1). The probability for errors of this nature (misspelling, spacing) would have been likely. However, we still needed to produce an electronic version for the sake of circulation and potential publication. The poem was in fact published in a Brazilian journal called $O$ Tranca Rua (see Plates 2 and $3)$. We noticed that there were a few minor and major errors in their version, for example, the misspelling of prut and supper. But to return to the idea of sensitivity to voice and language, I would like to refer to the line -'Ek bly in $\mathrm{n}$ huis in La-la dorp'. 'La-la dorp' is a colloquial expression. It would have been quite easy for us to come up with a similar (more accessible) expression. In fact, we could have expressed the same idea in English. However, it would not have had the same significance nor signalled the 'societal exclusion' and identity ideas which are, in this context, only authentic in Afrikaans. In my opinion, the line has its own backstory. It carries a similar kind of significance, much like the history that surrounds the title "Quebre o Forno".

\section{CLOSING REMARKS}

The poem was written in the space of one hour. Apart from the limited time, we also had to combine three equally critical stages in any writing process into one. We needed to use the hour for the pre-writing (the conversations), the drafting and the editing of the poem. In my own work, I am very conscious about overstating ideas. However, producing a multilingual poem is slightly different. A multilingual poem is made up of multitudinous voices. It has several authors and one therefore places less insistency on what is being said and more on how it is being said. The poem has since been published in Brazil in a journal. Through some correspondence with the editors of $O$ Tranca Rua (see Plate 4), I have come to learn that the journal is named after an Afro-Brazilian deity praised as the lord of communication. The deity is praised for being responsible for connecting the gods to humans. A direct translation into English would read -'Street locker' or 'The one that

Zannie Bock <zannie.bock@gmail.com>

Nov 6, 2018, 11:07 PM

to Nondwe, Lisa

Thanks Lisa!

Also: the title should be Quebre o forno (according to Fernanda :)

Complicated business, this multilingual writing! 
locks the streets'. I found this to be an interesting parallel with the dynamism and inclusivity of multilingualism. Additional correspondence between myself and Nondwe and Zannie Bock, and re-printed as a footer to this reflection, traces the complexities and challenges of working with multiple languages.

\section{REFERENGES}

Dickinson, Emily. 1998. The Poems of Emily Dickinson: Reading Edition. Harvard University: The Belknap Press.

Fargion, Janet. "Song as oral tradition in West Africa". The British Library: https://www.bl.uk/west-africa/articles/ song-as-oral-tradition-in-west-africa

Keene, D. 1995. Japanese Literature: An Introduction for Western Readers. New York: Grove Press.

Lisa Julie <lilyjulie68@gmail.com

Nov 6, 2018, 11:09 PM

Oh dear, I missed that. Tricky business indeed.

Happy to help. 
Quebre o forms

33

Rice is boiling - steaming wrindarts, steaming windows, borbulhandou pret.

Each time I enter the kitchen I cask myself - why a TV? Withy a pile of dishes? Why a spoon in the microwave? tach time I enter, the kitchen I hear - what's for super.' Who opened anther milk? Who $6 / t$ the milk out?

Helequadaty in a' his is lala dep $x$. Is die heirs menses tier? Ndayiqanda ndiblala kumzi owawuhlala umama Imbiza zatsha!!!

Plate 1: Hand written version of the poem
O MULTILÍNGUE

per anna isabel freire, asithandile nozemi, caitlin o'donovan, fernando alencar, lauren abraham, keshia jansen, lisa julie, lulu duce, marcelyn oostendorp, tan dick

QUEBRE O FORNO

Rice is boiling steaming windows, borbulhando.

pret.

Each time I enter the kitchen, I ask myself - why a TV?

Why a pile of dishes?

Why a spoon in the microwave?

Each time I enter the kitchen, I hear - what's for super?

Who opened another cart of milk?

Who left the milk out?

Ex fly in $n^{\prime}$ his in Lala dorp:

- Is die hus mene her?

Ndayiqanda ndihlala kumzi awawuhlala umama Imbiza zatsha!!! •

Plate 2: Enlargement of poem in O Tranca Ru. 

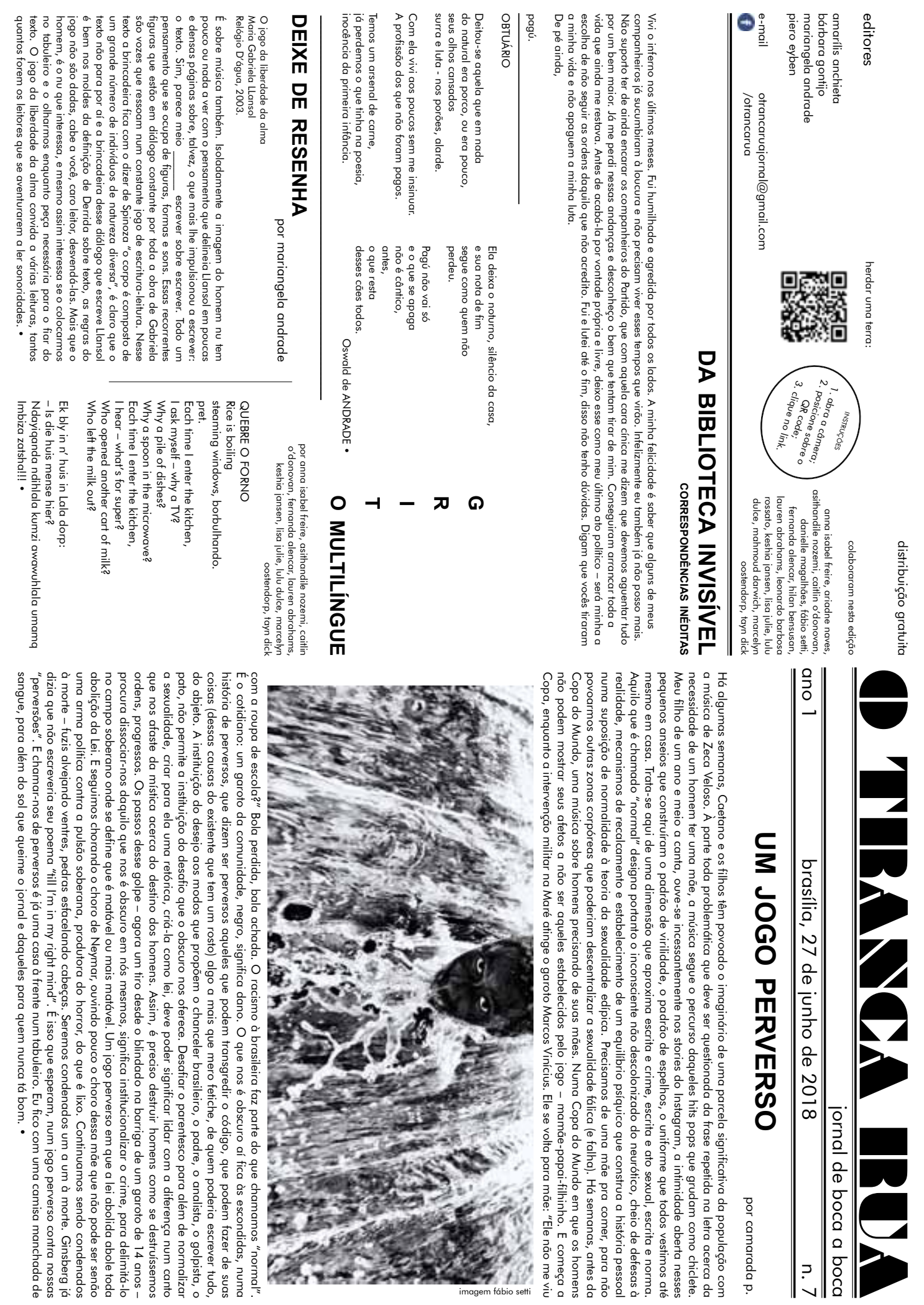

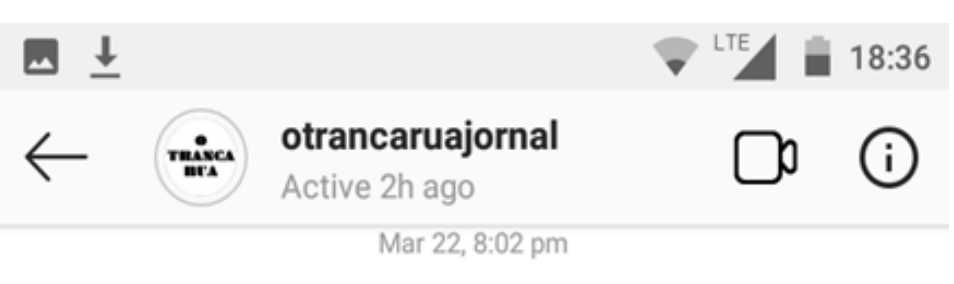

Hey Lisa. Good afternoon. I'm sorry for the delay answer. I hope we can still be helpful.

Our journal has no religious connection or content, that's pretty clear, right? It's name is also a name of an afrobrazilian deity praised to be lord of communication. Legendary responsible to make the connection between all the others deity and humans. If we were to literally translate

his name would be "Street Barrier" "street locker" something like that.

Does it answer your question?

Please let us know if you need any more info. Thanks for your contact.

$\underset{\text { mixses }}{\min } \mathrm{O}$ Double-tap to like

Good day. Thank you very much. It definitely helps.

All the best from sunny Cape Town. $0 \div$

(O) 싱 


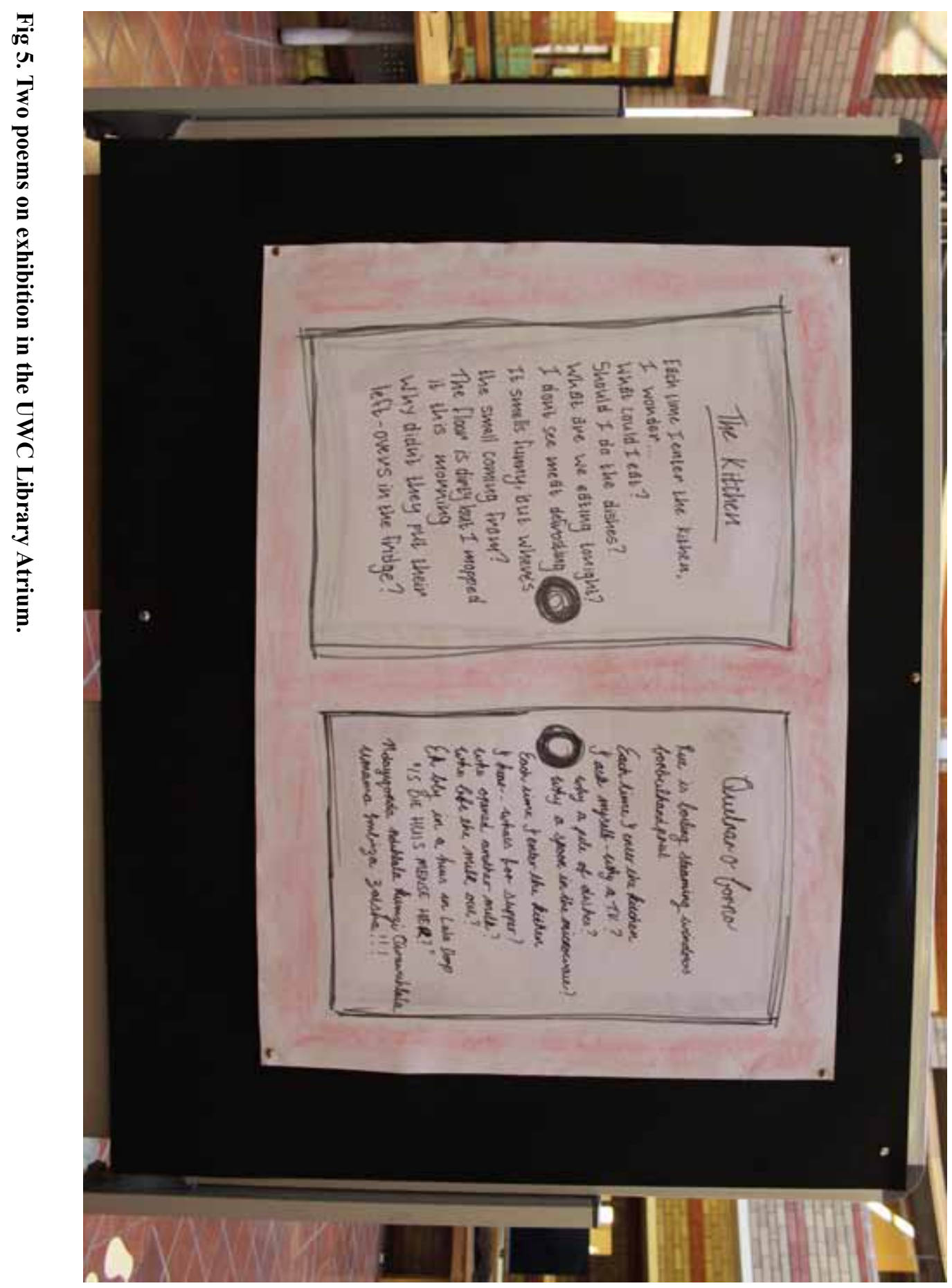

